\title{
ПОНЯТІЙНО-ТЕРМІНОЛОГІЧНІ ОСНОВИ ІНКЛЮЗИВНОГО ТУРИЗМУ ЯК НОВОГО НАПРЯМУ РОЗВИТКУ РЕГІОНАЛЬНОЇ ЕКОНОМІКИ
}

\section{CONCEPTUAL AND TERMINOLOGICAL FUNDAMENTALS OF INCLUSIVE TOURISM AS A NEW DIRECTION OF DEVELOPMENT OF THE REGIONAL ECONOMY}

\author{
Ладонько Людмила Степанівна \\ доктор економічних наук, доцент, \\ Київський національний торговельно-економічний університет \\ ORCID: https://orcid.org/0000-0001-5982-7684 \\ Переверзєва Анна Василівна \\ доктор економічних наук, доцент, \\ Запорізький національний університет \\ ORCID: https://orcid.org/0000-0001-8391-6636 \\ Ladonko Liudmyla \\ Kyiv National University of Trade and Economics \\ Pereverzeva Anna \\ Zaporizhia National University
}

\begin{abstract}
У статті розглянуто основні теоретичні основи туризму як галузі соціально-економічного розвитку країни, 3 акцентом на понятійно-термінологічний апарат інклюзивного туризму як нового наукового напрямку туристичної сорери. Надані основоположні визначення поняття «туризм», виходячи з напрямку та тематики наукових досліджень вчених, що займаються цим питанням. Окремо надається тлумачення поняття «інклюзивний туризм» і дотичних до даного поняття синомічних варіантів, які розкривають їх сутність і практичні можливості. Для візуалізації варіативності різноманітних тлумачень, пропонується схематичне зображення у вигляді категорій вивчення поняття «туризм», в тому числі й «інклюзивний туризм», що вказує на багатогалузевість використання даного терміну та різноманітність підходів до його визначення. Описується проблематика використання понятійно-термінологічного апарату та перспективи його удосконалення.
\end{abstract}

Ключові слова: понятійно-термінологічний апарат, туризм, інклюзивний туризм, регіональна економіка, категорії туризму.

В статье рассмотрены основные теоретические основы туризма как отрасли социально-экономического развития страны, с акцентом на понятийно-терминологический аппарат инклюзивного туризма как нового научного направления туристической сферы. Предоставлены основополагающие определения понятия «туризм», исходя из направления и тематики научных исследований ученых, занимающихся этим вопросом. Отдельно предоставляется толкование понятия «инклюзивный туризм» и касающихся данного понятия синомичных вариантов, которые раскрывают их сущность и практические возможности. Для визуализации вариативности различных толкований, предлагается схематическое изображение в виде категорий изучения понятия «туризм», в том числе и «инклюзивный туризм», что указывает на многоотраслевое использование данного термина и разнообразие подходов к его определению. Описывается проблематика использования понятийно-терминологического аппарата и перспективы его совершенствования.

Ключевые слова: понятийно-терминологический аппарат, туризм, инклюзивный туризм, региональная экономика, категории туризма.

The article discusses the main theoretical foundations of tourism as a branch of the country's socio-economic development, with an emphasis on the conceptual and terminological apparatus of inclusive tourism as a new scientific direction in the tourism sector. Provided the fundamental definitions of the concept of "tourism", based on the direction and topics of scientific research of scientists dealing with this issue. Separately, the interpretation of the 
concept of "inclusive tourism" and the synomical options related to this concept are provided, which reveal their essence and practical possibilities (adaptive tourism, barrier-free tourism, rehabilitation tourism, inventourism, tourism is available to everyone and others). To visualize the variability of different interpretations, a schematic representation is proposed in the form of categories for studying the concept of "tourism", including "inclusive tourism", which indicates the multi-sectoral use of this term and a variety of approaches to its definition. Scientific publications are characterized, the subject of which is closely related to inclusive tourism, revealing its features and pointing out the principles, forms, factors of its development, as well as its practical application. It was found that until now there is no unified definition of the concept of "inclusive tourism". Attention is focused on the fact that inclusive tourism attracts about 50 sectors of the national economy to comprehensive services, confirms the opinion that the tourism sector is multi-galuzeva and universal. To understand the features of inclusive tourism, examples of those persons who can be classified as inclusive tourists are offered. The problems of using the conceptual and terminological apparatus and the prospects for its improvement are described. Emphasis is placed on the fact that inclusive tourism can be considered as a revenue-expenditure component of socio-economic development of regions with the involvement of investment programs and the use of innovative technologies. Examples of the development of inclusive tourism in the EU countries to understand the role and place of inclusive tourism in the field of tourism services are given.

Keywords: conceptual and terminological apparatus, tourism, inclusive tourism, regional economy, categories of tourism.

Постановка проблеми. Беручи до уваги світовий досвід надання туристичних послуг для людей з інклюзією, Україна розвиває і поступово вводить новий напрямок туристичної ссрери як інклюзивний туризм, завдяки якому можна залучити до туристичної діяльності близько мільйона осіб для яких туристичні подорожі були практично недоступні через фрізичні та фрінансові проблеми.

Для успішної реалізації планової стратегії розвитку інклюзивного туризму в Україні, необхідно мати матеріально-технічну, інфраструктурну та ресурсну бази, що дозволило б розвивати та впроваджувати інклюзивний туризм, з урахуванням вимог, механізмів та можливостей регіонів.

Одним 3 основних аспектів формування нового наукового напрямку як інклюзивний туризм, $є$ його теоретико-методологічна основа з чітко визначеним понятійно-термінологічним апаратом, який може бути як уперше прописаним і обґрунтованим, так і мати певні уточнення.

Враховуючи новизну розвитку та впровадження інклюзивного туризму в регіональну систему соціально-економічних відносин, ми спробуємо акцентувати увагу на основних положеннях і визначеннях, які розкривають сутність та характерні ознаки інклюзивного туризму.

Аналіз останніх досліджень і публікацій. В напрямі дослідження туристичної сфрери працювали наступні вітчизняні вчені: Алєшугіна Н.О. (Рекреаційно-туристичні ресурси України 3 основами туристичного ресурсознавства), Бармашина Л.М. (Концепція формування безперешкодного середовища життєдіяльності маломобільних груп населення), Гайдук А. (Інтегрований туристичний концерн - сучасна фрорма туристичного підприємства в умовах глобалізації) та закордонні: Бавельский А.Д. (Доступная среда как фрактор развития и безопасности безбарьерного туризма), Губа В.П. (Методы научного исследования туризма), Гуляев В.Г. (Туризм: экономика и социальное развитие) та інші.

Проблеми соціалізації і адаптації людей 3 інклюзивним до навколишнього середовища $€$ предметом наукового дослідження таких вчених, як: О. Бейдик, О. Любіцева, С. Богданов, Г. Гаврюшенко, О. Колупаєв, Н. Ніда, Н. Софрій, І. Ярмощук і ін.). Серед зарубіжних вчених дану тематику досліджували В. Преобеженскій, М. Мироненко, І. Твердохлєбов, І. Зорін, С. Сесолкін і ін.

Кожен з вчених пропонував свої підходи, форми та методи досліджень, виділяючи характерні ознаки та особливості теоретикометодологічних основ туризмознавства.

Мета дослідження. Метою даного наукового дослідження $€$ визначення теоретичних основ інклюзивного туризму як нового напряму соціально-економічного розвитку регіонів України та уточнення понятійно-термінологічного апарату, який розкриває сутність і особливості даного напрямку.

Виклад основного матеріалу дослідження. Туризм, як складне соціально-економічне явище, характеризується наявністю значної кількості визначень, які постійно змінюються, оновлюються, доповнюються, удосконалюються та, які не отримали загальноприйнятого визнання, а тому продовжують уточнюватися та вдосконалюватися.

Наприклад, Реймерс $\mathrm{H}$. розглядає туризм як будь-яку подорож 3 метою відпочинку і знайомства з новими регіонами й об'єктами» [11, с. 697], а Бейдик О. визна- 
чає туризм, як форму масових подорожей та відпочинку 3 метою ознайомлення 3 навколишнім середовищем, що характеризується екологічною, освітянською та іншими функціями [2, с. 95].

Крапф К. і Гунзикер В. вважають, що туризм - це сукупність відносин та явищ, які мають місце під час подорожей у певну місцевість за умови нетривалого поселення та нездійснення діяльності, що може спричинити отримання доході [6], а за думкою Крачило М. туризм - це різновид рекреації, активного відпочинку, під час якого відновлення працездатності поєднується 3 оздоровчими, пізнавальними, спортивними та культурно-розважальними цілями [12, с. 75]. Дані визначення підтверджуються Законом України «Про туризм» («Туризм - тимчасовий виїзд людини 3 місця постійного проживання в оздоровчих, пізнавальних або професійно-ділових цілях без зайняття оплачуваною діяльністю») [7, с. 11].

Якщо розглядати туризм в системі соціально-економічних відносин, то за визначенням Азара В. туризм характеризується як велика економічна система з різноманітними зв'язками між окремими елементами в межах народного господарства окремої країни, і зв'язків національної економіки зі світовим господарством загалом [9, с. 28].

В свою чергу Зорін І. і Квартальнов В. наводять різні десрініції поняття туризм: вид подорожі; рух (переміщення) поза місцем постійного проживання; срорма розумового та фрізичного виховання, що реалізується через соціально-гуманітарні фрункції; популярна фрорма організації відпочинку, проведення вільного часу; галузь господарства, яка тимчасово надає послуги людям поза місцем їхнього постійного проживання; особлива фрорма пересування людей за маршрутом із метою відвідати конкретні об'єкти або задовольнити особисті потреби [7, с. 24].
Оскільки існує різноплановість понятійнотермінологічного апарату щодо фрормування поняття про туризм та туристичну діяльність, то логічним, на нашу думку, є процедура класисрікації їх у категорії за змістом та сутністю: соціально-культурний (функціональний), нормативний, міграційний та економічний туризм (рис. 1).

Вище викладені версії тлумачення поняття «туризм», ілюструють багатогранність підходів, наукових напрямів і тенденцій, власних уподобань та мають суб'єктивний характер (виглядають або занадто розширеними й описовими, або звуженими). Це вносить плутанину в їх тлумачення чи робить їх синонімічними з аналогічними визначеннями інших ссрер людської життєдіяльності.

В останні 10 років (2011-2021рр.) активно поширюється новий науковий напрям - інклюзивний туризм. Іноді його називають «туризмом для всіх» або «туризмом без бар'єрів», тобто таким туризмом, який дозволяє «бачити світ» всім без винятку.

Починаючи 32016 року про інклюзивний туризм як вид реабілітації заговорили і в Україні. Це підтверджується низкою публікацій та заходів, серед яких I міжнародний науковопрактичний симпозіум «Актуальні проблеми впровадження інклюзивного реабілітаційносоціального туризму в Україні», що відбувся в 27-29 жовтня 2016 року в м. Умані на базі Уманського державного педагогічного університету ім. Павла Тичини.

Виникає питання теоретико-методологічного обґрунтування даного напрямку, 3 подальшим визначення принципів, фрорм, методів і узгодження понятійно-термінологічного апарату.

Термін «інклюзивний туризм» має різні інтерпретації і тлумачення. Даний термін має синомічні поняття як «туризм для всіх» (tourism for all), «доступний туризм» (accessible tourism), «туризм для інвалідів», «інватуризм», «паратуризм», «безбар'єрний

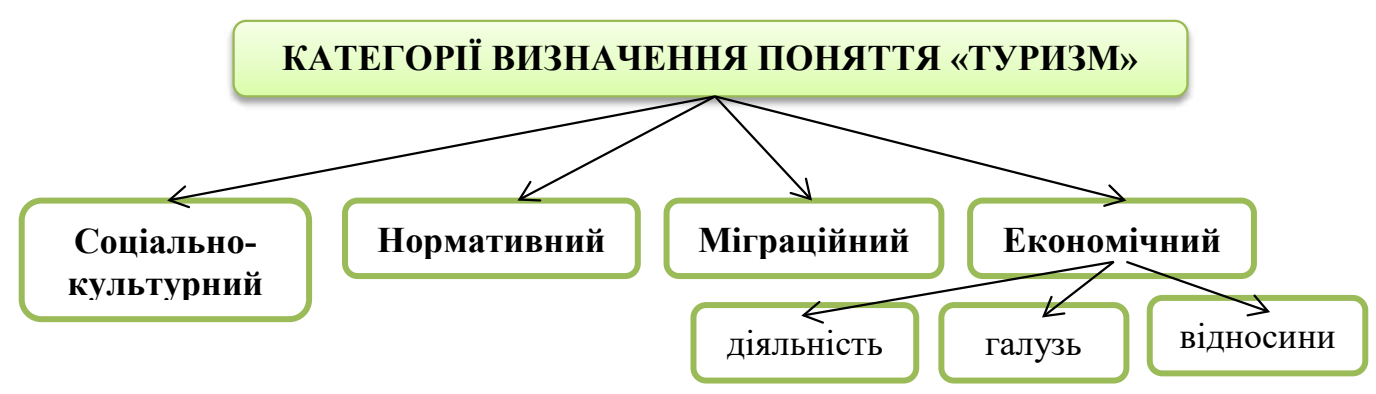

Рис. 1. Система категорій визначення поняття «туризм»

Джерело: побудовано за даними [8] 
туризм», «реабілітаційний туризм», «корекційно-навчальний туризм» та інші [3]. Все залежить від того, в якому напрямку відбуваються наукові дослідження даної тематики та що $є$ основною метою цих досліджень. Але до цих пір уніфрікованого визначення поняття «інклюзивний туризм» не існує.

Останнім часом доволі часто для характеристики туристичної діяльності, в рамках надання специфрічних (особливих) послуг для інклюзивних туристів, застосовується термін «адаптивний туризм». При цьому звужується уявлення про реабілітаційні можливості (акцентується увага тільки на адаптації в інклюзивному середовищі) та, як наслідок, відбувається підміна поняття «реабілітація» (в повному його розумінні) на поняття «адаптація». А це різні поняття, що мають відмінності як у лінгвістичному, так і в науково-практичному сенсі (реабілітація - оздоровлення, відновлення фрізичного та емоційного стану людини, а адаптація - пристосування людини до певних умов чи середовища). У даному контексті терміни «інклюзивний туризм» і «туризм, доступний для всіх» часто сприймаються як слова-синоніми, а ось «адаптивний туризм» розглядається як рівень пристосованості до певних умов життєдіяльності людини та як соорму туристичної діяльності.

Необхідно зазначити, що остаточну версію терміну «туризм, доступний для всіх» (Accessible tourism for all), запропонували на 16-тій сесії Генеральної Асамблеї ЮНВТО, у Дакарі (2005р.), а вже у 2009 році на 18-й сесії Генеральної Асамблеї ЮНВТО в Астані (Казахстан) цей термін набув остаточний варіант у документі під назвою «Декларації зі спрощення туристських подорожей» [1, р. 130-137].

В країнах Євросоюзу сегмент туризму для людей 3 обмеженими можливостями називають «доступним туризмом» або «туризмом для всіх». При цьому сутність такого виду соціальної реабілітації не змінюється [4, с. 12-16]. Саме термін «туризм, доступний для всіх» (tourism for all) сьогодні відображає основний зміст, закріплений у міжнародних нормативно-правових актах, так як і термін «безбар'єрний туризм», який відображає ступінь пристосованості об єктів показу, доступності туристичного середовища до потреб туриста [5, с. 129].

Як правило, таке різноманіття термінів обумовлює концепцію створення єдиного доступного простору для людей з інклюзією.
Розглядаючи інклюзивний туризм з точки зору соціально-економічного підходу, можна звернути у вагу на те, що якісне обслуговування туристів $€$ джерелом доходів для місцевих територіальних громад. Туризм не вимагає значних інвестицій, але відрізняється високим рівнем рентабельності впродовж незначного терміну часу, що надає можливість розвивати сегменти малого та середнього бізнесу, де ключовим моментом $€$ створення додаткових робочих місць і забезпечення зайнятості населення (для обслуговування одного іноземного туриста потрібно до 10 фрахівців туристичної галузі) [10, с. 31].

Інклюзивний туризм побудований на співробітництві між різними учасниками туристичної сорери, що дозволяє людям подорожувати самостійно незалежно від того, чи є у них якісь особливі потреби. При цьому мова не йде виключно про людей з інвалідністю, це лише одна з категорій. Труднощі можемо відчувати в той чи інший момент всі ми, наприклад, опинившись в країні, мовою якої не говоримо. Під час подорожей труднощі можуть виникати у людей похилого віку - їм, наприклад, не завжди підходить звичайний темп екскурсоводів. Людям високого зросту буває непросто улаштуватись у транспорті, а людям низького зросту - дотягнутися до стійки реєстрації в готелі або до кнопки в лісрті.

А тому, інклюзивний туризм можна розглядати як сегмент туристичної галузі, яка останніми роками є одним з основних елементів економічної стабільності країни. Окрім того, туризм, в тому числі й інклюзивний туризм, залучає до комплексного обслуговування близько 50 галузей народного господарства, що підтверджує думку про те, що туристична сорера $€$ мультигалузева та універсальна.

Висновки 3 проведеного дослідження. Виходячи з вище сказаного необхідно відмітити, що:

1. Дослідницька робота з питань узгодження понятійно-термінологічного апарату з туризму, повинна тривати та всіляко підтримуватись і державою, і зацікавленими бізнесовими туристичними структурами.

2. Інклюзивний туризм можна розглядати як комплексний і міждисциплінарний напрям соціально-економічного розвитку регіонів України, з урахуванням особливостей ресурсного потенціалу регіонів, при наявності матеріально-технічної бази та рівня їх економічного розвитку, а також згідно нормативно-правових документів, що регулюють процедуру надання туристичних послуг. 


\section{СПИСОК ВИКОРИСТАНИХ ДЖЕРЕЛ:}

1. Бєлоусова Н.B. Development of inclusive rehabilitation-social tourism in Ukraine. Наукові записки Сумського державного педагогічного університету імені А.С. Макаренка. Географрічні науки. 2019. Вип. 10. С. 130-137.

2. Бейдик О.О. Тлумачний словник термінів з рекреаційної географрії (географрія туризму). Київ, 1993. 56 с.

3. Борущак М. І. Стратегія розвитку туристичних регіонів : монографія. Львів : Інтелект-Захід, 2008. 280 с.

4. Дерев'янко С. Соціально-економічне становище інвалідів в Україні та проблеми їх соціального захисту за умов транссормаційної економіки. Україна: аспекти праці. 2005. № 4. С. 12-16.

5. Жук М.В. Експортний потенціал регіону: теорія, методологія, практика. Чернівці : Рута, 2002. 199 с.

6. Изард У. Методы регионального анализа: введение в науку о регионах / Сокр. пер. с англ. В.М. Гохмана, Ю.Г. Липеца, С.Н. Тагера ; вступ. ст. и редакция А.Е. Пробста. Москва : Прогресс, 1966. 643 С.

7. Квартальнов В.А. Туризм. Москва : Финансы и статистика, 2002. 320 с.

8. Колосінська М.І. Дослідження теоретичних підходів до визначення категорії «туризм». Економіка. Управління. Інновації. 2011. № 2(6). С. 67-75.

9. Максимова Т.С. Регіональний розвиток (аналіз та прогнозування) : монографрія. Луганськ : видавництво СНУ ім. В. Даля, 2003. 304 с.

10. Мельниченко О.А. Особливості розвитку індустрії туризму в Україні : монографія. Харків : Видавництво НУЦЗУ, 2017. 153 с.

11. Регіональна політика України: інституційно-правове забезпечення : зб. офріц. док. / упоряд. 3. Варналій, В. Жук, А. Павлюк [та ін.] ; за ред. 3. Варналія. Київ : НІСД, 2004. С. 437-489. (Сер. «Регіональний розвиток». Вип. 6).

12. Сухоруков А.І. Моделювання та прогнозування соціально-економічного розвитку регіонів України : монограсрія. Київ : НІСД, 2012. 368 с.

\section{REFERENCES:}

1. Bielousova N.V. (2019) Development of inclusive rehabilitation-social tourism in Ukraine. Naukovi zapysky Sums'koho derzhavnoho pedahohichnoho universytetu imeni A. S. Makarenka. Heohrafichni nauky, 10, 130-137. (in Ukrainian)

2. Beydik O.O. (1993) Tlumachnyy slovnyk terminiv z rekreatsiynoyi heohrafiyi (heohrafiya turyzmu [Explanatory dictionary of terms on recreational geography (geography of tourism)]. Kyiv, 56. (in Ukrainian)

3. Borushchak M.I. (2008) Stratehiya rozvytku turystychnykh rehioniv: monohrafiya [Strategy of development of tourist regions: monograph]. Lviv: Intellect-West, 280. (in Ukrainian)

4. Derevyanko S. (2005) Sotsialno-ekonomichne stanovyshche invalidiv v Ukrayini ta problemy yikh sotsialnoho zakhystu v umovakh transformatsiynoyi ekonomiky [Socio-economic situation of disabled people in Ukraine and the problems of their social protection in a transformational economy]. Ukraine: aspects of labor, 4, 12-16. (in Ukrainian)

5. Zhuk M.V. (2002) Eksportnyy potentsial rehionu: teoriya, metodolohiya, praktyka [Export potential of the region: theory, methodology, practice]. Chernivtsi: Ruta, 199. (in Ukrainian)

6. Izard U. (1966) Metody regional'nogo analiza: vvedeniye v regional'nuyu nauku [Methods of regional analysis: an introduction to the science of regions] / U. Izard; sokr. pereulok. s angl. V.M. Gokhman, YU.G. Lipets, S.N. Tager; vstupleniye. Izobrazitel'noye iskusstvo. i otredaktiroval A. Ye. Probst. Moscow: Progress, 643. [in Russia]

7. Kvartalnov V.A. (2002) Turizm [Tourism]. Moscow: Finansy i statistika, 320. (in Russian)

8. Kolosyns'ka M.I. (2011) Doslidzhennya teoretychnykh pidkhodiv do vyznachennya katehoriyi «turyzm» [Research of theoretical approaches to the definition of the category "tourism"]. Ekonomika. Upravlinnya. Innovatsiyi, 2(6), 67-75. (in Ukrainian)

9. Maksimova T.S. (2003) Rehional'nyy rozvytok (analiz ta prohnozuvannya): monohrafiya [Regional development (analysis and forecasting): monograph]. Luhans'k: Vydavnytstvo SNU imeni V. Dalya, 304. (in Ukrainian)

10. Mel'nychenko O.A. (2017) Osoblyvosti turystychnoyi haluzi v Ukrayini: monohrafiya [Features of the tourism industry in Ukraine: monograph]. Kharkiv: Vydavnytstvo NUTSZU, 153. (in Ukrainian)

11. Rehional'na polityka Ukrayiny: instytutsiyno-pravove zabezpechennya: zb. ofitsiy. dok. (2004) [Regional policy of Ukraine: institutional and legal support: collection. ofits. dock.] Zamovlennya Z. Varnaliy, V. Zhuk, A. Pavlyuk [ta in.]; dlya zamovlennya. Z. Varnaliya. Kyiv: NISD, 437-489. (Ser. «Rehional'nyy rozvytok», vol. 6). (in Ukrainian)

12. Sukhorukov A.I. (2012) Modelyuvannya ta prohnozuvannya sotsial'no-ekonomichnoho rozvytku rehioniv Ukrayiny: monohrafiya [Modeling and forecasting of socio-economic development of the regions of Ukraine: monograph]. Kyiv: NICD, 368. (in Ukrainian) 